\title{
Reflexões Sobre a Violência e o Homem Contemporâneo
}

\author{
About violence and the contemporary human being
}

Resumo: Esta resenha propõe uma reflexão sobre a violência subjacente a determinadas situações humanas. Para tanto, foi feita uma análise do homem ocidental contemporâneo e de suas formas de vida, baseada em idéias das teorias psicanalíticas de Freud e Lacan e nas perspectivas de Heidegger e Merleau-Ponty. Nosso raciocínio parte do pressuposto de que a civilização só é capaz de inibir a agressividade do homem mediante promessas que o favoreçam. Assim, perguntamo-nos: que promessas são feitas hoje? Essa questão orienta nossas hipóteses sobre o homem atual, entre elas, a de que hoje há uma reificação da condição humana.

\section{Lara Cristina d'Avila Lourenço}

Psicóloga formada pela Universidade de

São Paulo (USP ) Ribeirão Preto). Mestre em Epistemologia da Psicologia e da

Psicanálise pela Universidade Federal

de São Carlos.

Doutoranda em

Tópicos Históricos e Culturais da Psicologia pela Universidade de

São Paulo (USP /

Ribeirão Preto). Bolsista pela CAPES.

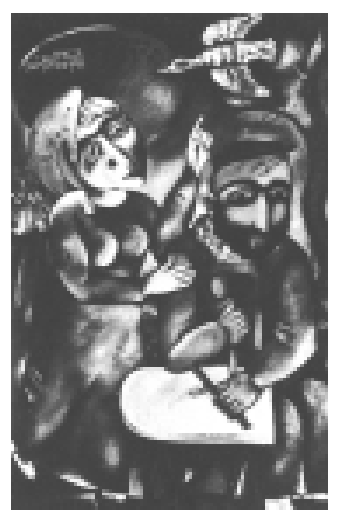

Palavras-Chave: Agressividade, civilização, homem, Psicanálise.

Abstract: This report proposes a reflection about the underlying violence of certain situations faced by human beings. An analysis of the contemporary occidental human beings and their ways of life was made based on the freudian and lacanian psychoanalytic theory and on Heidegger's and Merleau-Ponty's perspectives. Our interpretation presupposes that the only way civilization may inhibit man's aggressiveness is through promises that give support to the human beings. Thus, we ask ourselves: what promises are made today? This question guides our hypotheses about the human being, among them, the current objectivation of the human condition.

Key words: Aggressiveness, civilization, human being, Psychoanalysis.

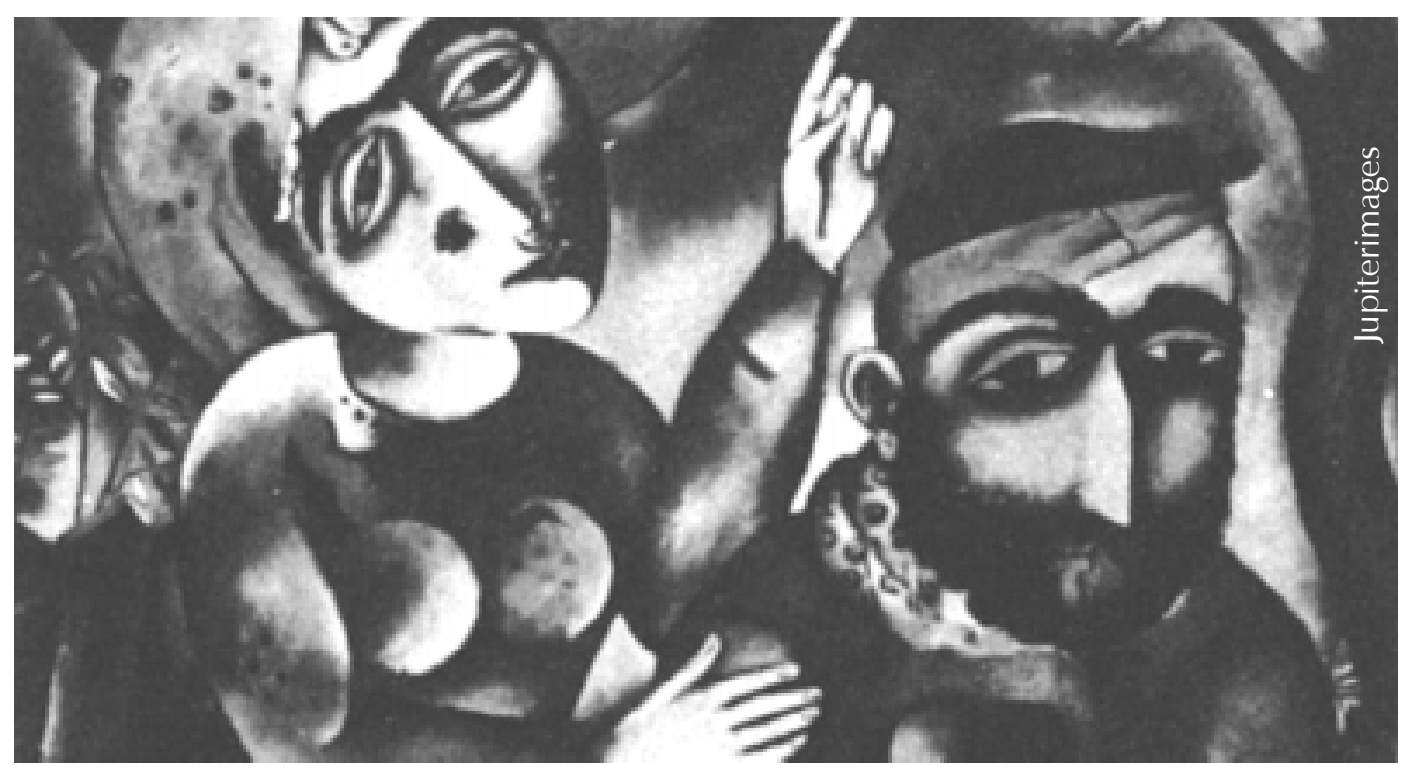

Atualmente, a violência tem estado no foco de nossas preocupações. É importante, então, conjeturarmos sobre algumas formas de manifestação e fatores propiciadores da violência hoje. Neste trabalho, abordamos alguns fenômenos cuja violência nem sempre é considerada como tal. Com esse propósito, fazemos uma breve reflexão sobre a essência do homem ocidental contemporâneo, porquanto acreditamos que diferentes interpretações do homem e da verdade fundam as características de épocas diversas.
Admitimos que o resultado de tal investigação é mais o levantamento de algumas questões que julgamos pertinentes do que propriamente a apresentação de conclusões.

Diante da opinião de Gadamer (Juranville, 1987), segundo a qual não podemos ter uma atitude objetivante a respeito da tradição porque estamos inseridos nela, aludimos à tese heideggeriana, que postula a idéia de que, através de um pensamento autêntico, o homem pode compreender a época 
em que vive, época que é, ao mesmo tempo, realizada e sofrida por ele.

O homem moderno já se sabe desprovido de atributos absolutos capazes de determinar o curso de sua vida de forma clara e contínua. Não há mais consenso sobre sua definição: ele não é mais somente criatura divina, não é mais guardião dos valores morais, não é simples máquina biológica.

\section{A Análise Freudiana da Agressividade na Civilização: o Jogo entre Promessa e Sacrifício}

Pensamos que a Psicanálise só pode surgir a partir desse momento de indefinição sobre a essência humana, diante do qual não recua ao considerar no homem um conflito fundamental entre duas sintaxes diferentes: a consciente e a inconsciente. Freud modifica o lugar da subjetividade ao reconhecer nela um não saber que sabe fazer, ou seja, ele retira do sujeito a autoridade da razão consciente, que Descartes havia proposto, porém sem transformá-lo em caos. A teoria psicanalítica, ao descrever o funcionamento inconsciente, aceita a lógica dos paradoxos da vida humana.

Como observa Merleau-Ponty (1960/1991), a teoria freudiana traz para a essência humana o corpo e o espírito não como dualidade, e, sim, como dialética. No homem freudiano, a carne ganha contornos a partir de suas relações com os outros; é uma carne que não só se encontra inserida nas relações sociais, como também as determina. Nessa dialética, não há lugar para a certeza absoluta.

É de acordo com essa lógica que Freud (1929/ 1980), em O Mal-estar na Civilização, afirma que, no aparelho psicofisiológico do homem, não há nada preparado para a obtenção da felicidade. Esta é apresentada apenas em momentos efêmeros, causados, na maior parte das vezes, pela cessação ou livramento da dor. Conforme o que comunica em Inibições, Sintomas e Ansiedade (Freud, 1926/ 1980), dor e ansiedade são justamente as sensações provenientes da incapacidade inata do aparelho psíquico em dominar adequadamente os estímulos internos e externos.

Tal condição faz da existência humana algo frágil e nada confortável. Estamos sempre ameaçados por perigos: somos sujeitos à fúria da natureza, à decadência de nosso corpo (que, muitas vezes, precisa utilizar-se da dor como sinal para se proteger), às dificuldades de nossos relacionamentos com os outros (Freud, 1929/ 1980).
A proposta ideal da civilização é a proteção contra tais perigos. A civilização providencia as religiões com seus deuses protetores, oferece o progresso científico e estabelece regras para os relacionamentos (regras que, como nota Freud, embora causem sofrimento aos indivíduos, possibilitam a vida em comunidade). Obviamente, toda essa promessa de proteção é feita sob a exigência de sacrifícios. Devemos sacrificar nossos impulsos mais primitivos, quais sejam, nossa agressividade e nossa libido.

Visando a esses sacrifícios, a civilização incentiva os sentimentos de identificação. Identificado com o próximo, não posso atentar contra a sua imagem, daí o mandamento: Amarás a teu próximo como a ti mesmo! Vale lembrarmos que Freud (1929/1980) se detém diante dessa ordem, argumentando que ela é totalmente contrária às tendências do homem. Afinal, argumenta o autor, se o amor é algo precioso, como dá-lo a qualquer um que se aproxime? Além disso, a agressividade, que caminha ao lado do amor, habita tanto no sujeito quanto no próximo, e, por isso, ambos recuam, temerosos com o afrontamento. Freud constata que a impossibilidade de tal mandamento ser efetivado traz justamente seu alcance no tempo.

Sobre a força dos mandamentos, lembramos ainda mais uma observação freudiana segundo a qual proibições poderosas só podem ser dirigidas contra impulsos igualmente poderosos, isto é, só precisa ser proibido aquilo que é fortemente desejado. Por isso, referindo-se ao mandamento: Não matarás!, Freud (1915/1980) conclui pela nossa sede de matar.

É importante recordarmos que a energia dos impulsos faz com que, mesmo quando inibidos ou transformados em seus opostos, eles irrompam em determinadas situações. Sabemos que não há proibição suficiente para impedir tais episódios, uma vez que, para a Psicanálise, a própria lei (que proíbe a violência) tem suas origens nos interesses violentos de um grupo de indivíduos. A respeito da lei, Freud diz: "Estaremos fazendo um cálculo errado se desprezarmos o fato de que a lei, originalmente, era força bruta e que, mesmo hoje, não pode prescindir do apoio da violência" (Freud, 1933[1932] / 1980, p. 251).

Pelos propósitos da civilização, a libido desenfreada é delimitada pelos ideais de ternura e pelas tentativas de normativização do amor. Conforme o autor (1921/1980), é a inibição dos impulsos sexuais que permite a união permanente entre as pessoas. Isso porque, quando satisfeitos, tais impulsos são facilmente enfraquecidos ou extintos, ao passo que, inibidos em seus objetivos, podem durar. Dessa forma, os impulsos sexuais são mesclados aos componentes afetivos necessários ao laço mútuo entre os indivíduos de um grupo. 
A agressividade, proibida de exteriorizar-se livremente, deve voltar para seu lugar de origem, isto é, contra o próprio sujeito. Esse é o fundamento, segundo Freud (1929/1980), do sentimento de culpa tão imprescindível à sobrevivência da civilização, pois, quanto mais culpa um indivíduo sente, maiores são suas auto-exigências morais. Em outros termos, conforme aumentam as renúncias pulsionais, maiores são as exigências do superego.

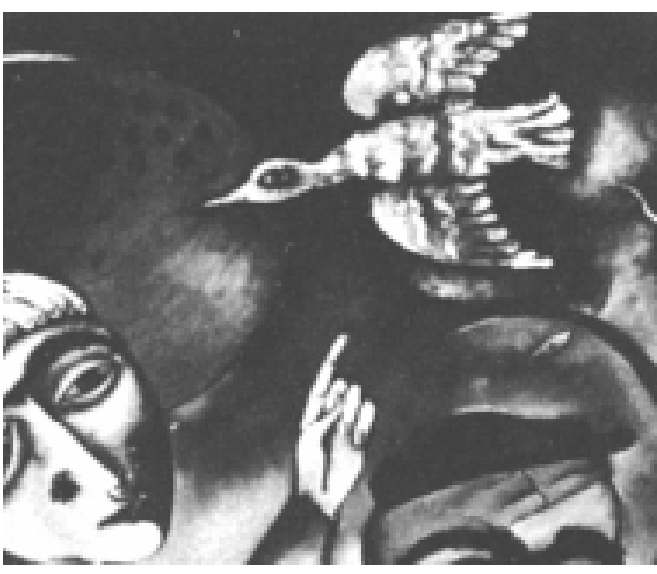

Dessa maneira, aprendemos desde muito cedo a aceitar as privações sobre o fundo de promessa. As ordens parentais, e, posteriormente, as ordens estatais e religiosas, são obedecidas em troca das promessas de amor, proteção e ideais de felicidade. Desiste-se dos desejos mais primevos e suportamse as mais severas punições na esperança de um futuro promissor.

\section{O lugar da Função Paterna: Lacan e a Dialética Hegeliana}

Visando ao objetivo de nossas reflexões, perguntamo-nos: que promessas são feitas hoje pela nossa civilização? Há repressão dos impulsos em nome de quê? Qual o lugar da culpa nas nossas sociedades?

Obviamente, em uma época em que não há definição absoluta do homem, não se considera mais a noção de um Bem Supremo, isto é, um Bem universalmente aceito e privilegiado. Logo, o homem não sabe mais, de antemão, qual deve ser o alvo de suas ações. Nesse quadro, onde pode localizar-se a questão da Ética?

Kant, de quem inegavelmente herdamos as noções de Ética, declara, no final do século XVIII, que o homem deve agir de tal forma que sua ação possa ser tomada como máxima universal. Talvez pode mais autenticar uma teoria sobre a verdade. Dessa forma, há várias teorias defendidas sem que exista realmente crença em alguma delas e sem que sejam de fato conhecidas, uma vez que surgem e desaparecem com extrema rapidez. O resultado disso é o cinismo das nossas sociedades que, exatamente nessa situação, fingem deter o conhecimento de tudo.

Segundo Lacan (1960/1991), a noção de um Bem Supremo foi substituída pela idéia de utilidade, isto é, o homem deve buscar aquilo que the seja útil. Esse autor entende que um dos fatores que levaram a tal substituição foi o declínio do que ele denomina função do mestre.

O mestre, de quem nos fala Aristóteles no século IV a.C., detém um conhecimento a ser comunicado ao discípulo. A decaída do mestre significa que, na época em que não há privilégio da sabedoria, e, sim, da rapidez de informações, não há mais um detentor do saber. Não reconhecemos mais um Outro capaz de ditar-nos as normas e, dessa forma, fornecer-nos nosso próprio reconhecimento, isto é, dizer-nos quem somos.

Hegel, em Fenomenologia do Espírito, apresentanos, no final do séc. XVII, um mestre já desprovido de uma sabedoria almejada e até mesmo um tanto tolo. Por isso, as relações desse mestre não são mais com o discípulo, mas com o escravo. Contudo, ainda é um mestre que, mesmo na ignorância, é capaz de nortear os caminhos do escravo. A tese de Hegel diz: a condição propriamente humana só é alcançada a partir do momento em que o desejo não visa mais às coisas naturais, mas a um outro desejo. Em outras palavras, isso significa que o desejo humano é o desejo de ser reconhecido pelo outro. É com essa tese que ele apresenta a dialética do Senhor e do Escravo: o Escravo trabalha para ser reconhecido pelo Senhor e, assim, sair de sua condição escrava. $O$ trabalho, aqui, traz a noção de mudança, na medida em que, através dele, o Escravo realiza uma transformação do dado natural que representa o desejo de transformar sua condição de escravo. Apesar de o reconhecimento buscado nunca ser de fato concluído, tal como observa Lacan ( $\mathrm{D}^{\prime}$ Avila Lourenço, 2000), o Escravo tem sempre o Senhor no seu horizonte, o que viabiliza a manutenção e direção do seu desejo.

Não deixa de ser interessante apontarmos a opinião de Lacan sobre a dialética hegeliana. De acordo com esse autor, embora tal dialética mostre que é pelo outro e através do outro que começa a haver reconhecimento da própria imagem, ela não possibilita ao Escravo a assunção de uma subjetividade autônoma, pois o desejo do Escravo é sempre alienado no desejo do Senhor. 
Essa é, conforme Lacan, a situação da criança em relação ao desejo da mãe no primeiro tempo do complexo de Édipo. Nesse momento, a criança tem seu desejo submerso no desejo materno: seu desejo é o de ser desejada pela mãe, que é, por esse motivo, quem lhe comunica a imagem a ser adotada (daí Lacan relacionar a imagem egóica à voz da mãe). A palavra do pai, inserindo-se nessa relação dual, é capaz de distinguir os desejos envolvidos, nomeando-os. Isso significa que a função paterna é mostrar que a relação biológica e imaginária que une mãe e criança está submetida a uma ordem social, simbólica. Com um nome que a represente, a criança pode aceitar inserir-se e participar dessa ordem. Esse processo, intitulado Metáfora Paterna, fornece à criança a subjetividade própria. Contudo, esse ganho traz necessariamente a perda da crença de ser a imagem ideal para o desejo da mãe, ou seja, a assunção do sujeito social implica o sacrifício de uma dose de narcisismo. Cumpre esclarecermos, aqui, que a teoria lacaniana do complexo de Édipo traz conceitos da antropologia e lingüística estruturais, que conferem papel fundamental aos símbolos e, portanto, às palavras, na representação e formação do sujeito. Dessa maneira, Lacan nos diz que a função do que ele denomina Nome do Pai é mostrar que, além do desejo de reconhecimento, deve haver o reconhecimento do desejo.

Tendo em vista a teoria lacaniana sobre o Nome do Pai e os focos de nosso trabalho, questionamos se há e qual é hoje o lugar da palavra do pai.

\section{O homem Objeto na Época da Técnica: da Angústia à Indiferença Afetiva}

Lembrando que o trabalho do Escravo, em Hegel, representa o intuito de transformação necessário ao desejo humano, pensamos sobre o lugar do trabalho em nossa época. Para tanto, referimonos a Heidegger. Esse autor, entendendo a época atual como a Época da Técnica, declara que o homem se transformou na Besta do Trabalho, ou seja, o trabalho não é mais um meio para se buscar a realização de um desejo, mas é o próprio fim. Quando tudo está a serviço da Técnica, é o homem quem passa a ser objeto do trabalho, não o contrário. Ele não pode mais valorizar seu trabalho quando justamente espera em vão que o trabalho lhe dê um valor. Sem se concentrar nas críticas marxistas ao capitalismo, Heidegger afirma que o homem não sabe mais para quê trabalha porque, nessa época, não há espaço para o pensamento, mas somente para o cálculo, sendo o homem também calculado (Haar, 1990).
Podemos pensar que a Técnica esteja a serviço da utilidade. Úteis são sempre objetos. O próprio homem converteu-se em objeto, e, dessa maneira, foi tomado para estudo. De acordo com Heidegger (1960/1969), na época da Técnica, estudar significa tomar sob controle, sob representação. Não só os aspectos físicos, mas também os aspectos do espírito devem ser conhecidos para o cálculo, para o controle, ou seja, até as paixões são controladas: não mais sentidas, mas assistidas. Chegamos ao ponto de assistirmos, através dos chamados reality shows, a transformação da condição humana em caricaturas grotescas para exibição.

Enquanto tudo é tomado no espaço da representação, nada é deixado ao abismo do vazio. Sem lugar vazio, não pode haver criação. Sobre isso, cumpre reportarmo-nos à teoria heideggeriana sobre a angústia. Segundo tal teoria (Heidegger, 1927/1984), a angústia aponta para o desamparo original que caracteriza a condição humana, qual seja, a ausência de fundamentos para a própria existência e o fato de a morte ser uma possibilidade constante. Somente quando o homem escolhe assumir essa sua condição é que ele pode escolher as possibilidades que the são próprias e não mais se sujeitar àquelas que o senso comum the impõe. Com isso, o autor entende ser somente por meio da disposição para sentir a angústia, que aponta para o vazio determinador da origem da nossa existência, que podemos fazer as escolhas componentes do nosso destino (observamos que o termo destino não deixa de evocar a idéia de conteúdos transmitidos por alguma tradição). É na relação autêntica com o próprio destino que o homem pode respeitar, vivenciar sua relação com os outros. Quando o homem assume autenticamente a própria existência, os outros deixam de ser vistos como objetos úteis.

Ainda concordando com Heidegger (Haar, 1990), dizemos que o homem de hoje geralmente apresenta um estado afetivo de indiferença. Ele só se angustia perante a angústia, isto é, sua angústia existe justamente para evitar uma angústia pura, original. Podemos imaginar que essa fuga desesperada da angústia original se manifeste na neurose de angústia e na já vulgarmente denominada síndrome do pânico.

\section{As Drogas nas Relações de Consumo: Fetiche que Exclui a Experiência da Melancolia}

Seguindo esses comentários, perguntamo-nos como pode, na configuração atual, haver encontro com um destino próprio? Como fica a relação com os outros? Indagamos mesmo se há lugar para tais 
questões em uma sociedade que, cada vez mais, desresponsabiliza as pessoas por seus atos, uma sociedade que, por exemplo, enxerga sucesso no comercial de telefonia celular cuja proposta é que o aparelho telefônico fale por você. Tudo é feito por você: pensamentos, ações, sentimentos. É justamente aí que você pensa poder tudo. $\mathrm{Na}$ distração, perde-se a possibilidade de viver.

No mundo dos objetos úteis, o homem não apenas usa, mas também é usado. Quando tudo é para consumo, ele consome e é consumido. Esse consumo imediato é o que vemos na toxicomania, que não pode mais ser vista como uma fala sintomática, e, sim, como manifestação da ausência da fala, ou seja, talvez hoje a droga não aponte mais para um desejo recalcado, mas para a resignação ou o esquecimento do desejo singular. Segundo a Psicanálise, aquilo que é recalcado continua a se manifestar exigindo satisfação. É isso que a toxicomania atual não permite: ela faz o homem desistir de seus desejos (ou mesmo impossibilita que eles sejam construídos) e oferece em troca a felicidade química (Sinatra, 2000).

Como conseqüência desse acordo, às vezes imposto, há grande número de homens seduzidos pelos efeitos do Viagra e sem parceiras, de mulheres apaziguadas pelos ansiolíticos ou enamoradas de suas próteses de silicone e até mesmo de crianças obedientes aos antidepressivos. Tudo isso no domínio das drogas lícitas, no qual, com muita tranqüilidade, a palavra do médico foi substituída pelo medicamento, e as inseguranças diante do parceiro amoroso foram substituídas por um narcisismo quase absoluto.

No amplo consumo de drogas como cocaína, crack, êxtase e, mais recentemente, o poderoso depressor do sistema nervoso, conhecido como $\mathrm{GHB}$, o homem contemporâneo não assume a própria morte como uma possibilidade constante que deve levá-lo a um projeto de vida mais autêntico. Ao contrário, ele desafia cinicamente a morte. Afinal, ela é o único fato que permanece como limite quando foram destruídos os limites entre o público e o privado, os limites morais e geográficos (a respeito da destruição dos limites geográficos, Heidegger diz que o homem contemporâneo não tem mais lar).

Nesse desafio da morte realizado pelo toxicômano, há uma busca por um gozo direto, sem obstáculos, um gozo sem referência a um parceiro, logo, um gozo sem trocas e regras. Como observa Viganò (2000), o toxicômano não é mais homem ou mulher, mas somente consumidor. É com essa condição que ele se identifica, o que leva Lacan (Viganò, 2000) a dizer que a droga serve como prótese de identificação. A droga, dessa forma, é uma solução que inviabiliza as campanhas que tentam destruí-la sem oferecerem alternativas de resolução.

Todavia, resta saber onde encontrar tais alternativas se, hoje, o que denominamos justiça não tem leis definidas e aproxima-se do cômico; se, apesar da busca desenfreada por vivências religiosas, estamos indecisos e em dúvida quanto aos nossos deuses; se, muitas vezes, as relações parentais não comunicam mais palavras diretivas.

A droga pode ser vista como uma das saídas perversas encontradas pela sociedade para aplacar a melancolia que caracteriza os sentimentos de perda dos controles e dos domínios. De acordo com essa afirmação, a droga tem um papel social de fetiche. O problema é que, privada da experiência da melancolia, a sociedade não pode elaborar de fato novas verdades. Sem aproximarse de suas perdas, ela não compreende o que perdeu e o que pode ser criado.

O efeito de tal processo é um estado maníaco em torno das mercadorias, apresentadas em diversas formas. Por causa desse estado, não se consegue mais determinar o valor das mercadorias. Daí, a vida pode valer um par de tênis...Os sonhos podem ser comprados pelos presentes da prostituição...Há contrabandos de crianças, de órgãos do corpo... Se os valores das mercadorias nos confundem, ficamos perdidos ao trocá-las. Tomando a tese de Claude Lévi-Strauss, apresentada em Estruturas Elementares de Parentesco (1949), de acordo com a qual as sociedades se estruturam a partir de seus sistemas de trocas, perguntamo-nos: como fica a estrutura de uma sociedade cujo sistema de trocas não tem regras definidas? Em outros termos, podemos falar de uma sociedade na qual o homem não consegue estabelecer os critérios para realizar suas trocas; ele próprio, então, caoticamente, é trocado.

\section{Lei e Promessas da Civilização: Suas Conseqüências na Identidade Sexual e na Criminalidade}

Voltemos à questão já apresentada: que promessas são feitas aos homens hoje a fim de que eles aceitem o sacrifício de alguns de seus impulsos? Talvez possamos pensar que, atualmente, as promessas são feitas pelas mercadorias, as quais prometem exatamente a privação dos sacrifícios. O que nem sempre é explícito nesse jogo é que, às vezes, o próprio indivíduo é que é oferecido em sacrifício. Por exemplo, ele oferece sua história quando apaga as marcas de seu corpo com cosméticos ou cirurgias plásticas, destrói caras experiências 
quando troca sua dor pela alienação química ou desaparece quando obedece às normas da moda. Ao contrário do que se poderia esperar, essa indiferença em relação aos sofrimentos não traz alívios. É o que facilmente constatamos. A permissividade transforma a liberdade em ditadura: você deve poder e saber gozar com tudo! Se não responde à ordem, você é visto como um fracassado. Aliás, talvez não estejamos errados em dizer que a sociedade atual evita as frustrações e enfatiza os fracassos, fingindo esquecer que aquelas aprofundam e mesmo inauguram as percepções da realidade, enquanto esses tornam a realidade insuportável.

Essa perspectiva faz-nos pensar que, de certa forma, as normas protegem o sujeito porque delimitam o espaço próprio e o espaço do outro, isto é, as leis fornecem as bases das identificações em torno das quais o sujeito pode organizar-se.

Sem a perspectiva da própria identidade, o indivíduo tem dificuldades em saber qual o lugar de seu corpo. Ele se perde na escolha entre ser homem ou mulher (dizemos escolha porque não estamos nos referindo a uma distinção anatômica, mas a uma distinção psíquica, embora saibamos que aquela tem conseqüências nessa, tal como nota Freud [1925 / 1980]); assim, ele tem necessidade de experimentar tudo, em um jogo no qual homens e mulheres, muitas vezes, não fazem mais diferença (tal como já dissemos ocorrer na toxicomania). Há a busca pelo aclamado gozo absoluto, que pode ficar mais próximo quando se goza com o próprio corpo e, não raro, quando se aproxima da morte.

Pensamos que a compreensão dessa lógica do gozo é fundamental para o tratamento de alguns casos de anorexia, cujos números aumentam consideravelmente. Aproveitamos para perguntarnos sobre o lugar da anoréxica nas nossas sociedades. A anoréxica mostra-se, drasticamente, como produto do discurso que transforma os homens em objetos. Ela tem, mais que qualquer outro, o corpo coisificado, insensível aos sofrimentos causados pela desnutrição. Exposta aos olhares chocados dos outros e ao olhar investigativo dos médicos, denuncia a ordem incongruente e perversa dos padrões estéticos.

São várias as tentativas de driblar os percalços nos processos de identificação e suas conseqüências nos relacionamentos sexuais. Entre tais tentativas, estão as buscas de alguns jovens por ideais caducos como a virgindade ou por dogmas de seitas religiosas. Em alguns desses casos, é alcançado um confortável mascaramento da situação.

Obviamente, não é nossa pretensão apontar possíveis saídas para as situações aqui descritas, tampouco abordamos as características de nossa época como progressos ou retrocessos em relação às épocas anteriores. Portanto, não valorizamos a adoção ou o abandono de antigos padrões sociais; apenas acreditamos ser importante o questionamento do estado atual de nossa sociedade, formada pelos homens e, concomitantemente, formadora dos mesmos.

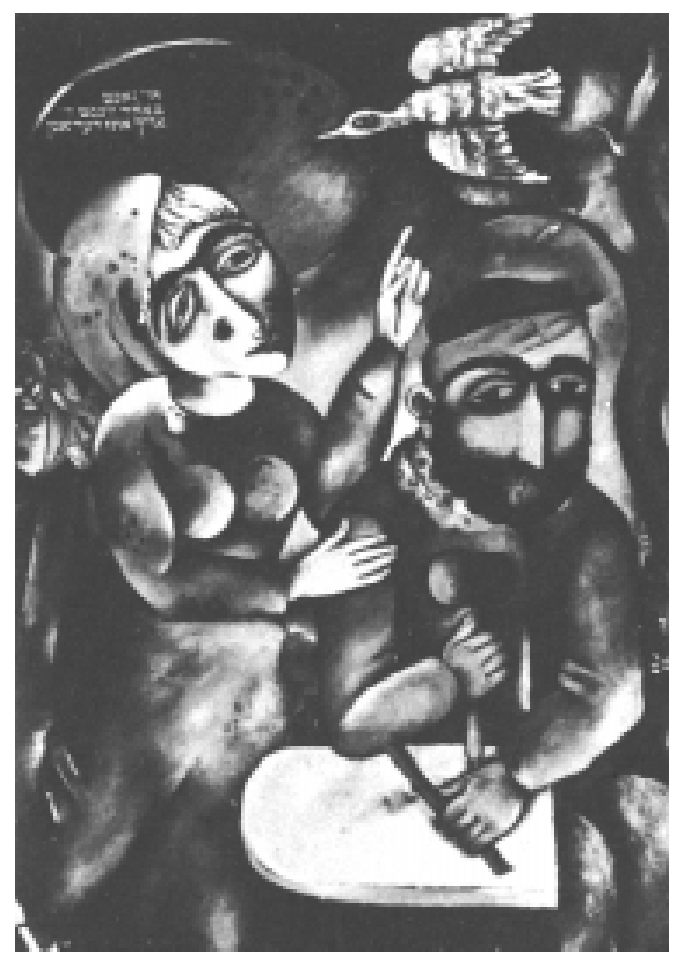

A atenção para com os caminhos dessa formação e para com o estatuto da violência nela contido certamente leva-nos a pensar sobre as políticas estatais e as guerras.

A finalidade política da época cujo princípio está na utilidade perversa é o acúmulo de benefícios individuais. A carreira política, freqüentemente, é vista como uma possibilidade de enriquecimento fácil e os votos são vendidos em troca de favores. A perversão é visível no escárnio feito com a legislação brasileira. Aqui, alguns governantes recorrem exatamente à lei para garantir a continuidade de ações ilegais. Por exemplo: quando acusados de cometerem crimes, deputados podem pedir afastamento de seus cargos a fim de evitarem a cassação de seus mandatos e, assim, são muitas vezes reeleitos, garantindo a oportunidade (em virtude da denominada imunidade parlamentar) de continuarem com suas ações corruptas.

Seguindo as linhas de nosso raciocínio, inquirimos: o que o Estado brasileiro promete aos seus 
cidadãos, a fim de que eles renunciem às vantagens que a criminalidade pode thes oferecer? Desemprego, impunidade e toda a sorte de desrespeito ao que é chamado direitos humanos não constituem um futuro almejado.

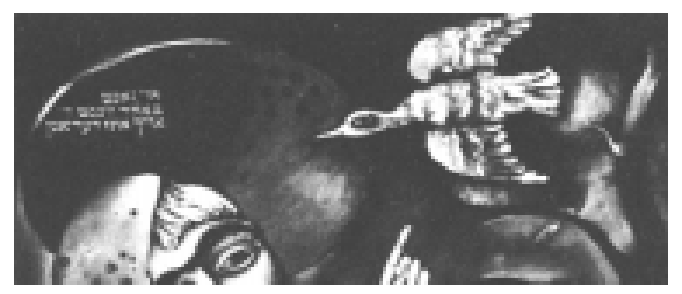

"Daí a estranha noção de ofensiva de paz: propor a paz é desarmar o adversário, é conseguir a adesão da opinião pública;

logo, é quase ganhar a guerra. Mas, ao mesmo tempo, sentese bem que não se deve ficar desmoralizado, que de tanto falar de paz encorajar-se-ia o adversário"

Merleau-Ponty
Logo, não é por acaso que hoje falamos em crime organizado: há uma organização porque a lógica entre sacrifício e promessa é respeitada. A submissão às regras do tráfico pode garantir a ascensão na hierarquia de seus membros e, conseqüentemente, poder, dinheiro. Nas relações do tráfico, há um apadrinhamento que, embora corrompido, dá aos aliciados uma orientação (na medida em que foram privados de uma orientação adequada). As crianças das favelas dirigidas por traficantes sabem que é a eles que devem respeitar. Para elas, a autoridade não pode mais ser dos pais, dos professores e, não raro, da polícia. Se tomarmos a tese psicanalítica, que vê, como uma das saídas para o medo, a identificação com o agressor, entenderemos que as crueldades do tráfico tendem a permanecer. O sucesso dos traficantes também é garantido porque eles fornecem à sociedade o dinheiro e a droga, a cujo forte papel social já aludimos anteriormente.

Nesse contexto, a crença e a obediência às leis (estatais, religiosas ou familiares) aparecem como ingenuidade pejorativa, ingenuidade da qual zombam os criminosos organizados que, muitas vezes, conseguem, entre outros feitos, fazer das penitenciárias suas agências do crime. Em um Estado cuja tradição de castigo está vinculada à prisão, isso abala os critérios de segurança pública. Por conseguinte, vemos uma população desnorteada quando constata que é tola até mesmo sua esperança de que criminosos sejam presos.

$\mathrm{Na}$ época da euforia em torno das mercadorias, a própria noção de mundo é baseada exclusivamente no poder econômico: o primeiro, o mundo mais evoluído, é constituído pelos países ricos; o terceiro designa os países pobres, submissos àqueles. Nessa classificação, as riquezas e peculiaridades culturais são negadas ou vistas como simples exotismo. Dessa forma, o mundo não oferece mais o abrigo de um lar; para alguns, ele passa a ser cativeiro, para outros, espaço a ser conquistado. Novamente referindonos aos pensamentos de Heidegger (Haar, 1990), destacamos que o homem atual, cada vez mais hábil em percorrer distâncias e conquistar territórios, não tem um território familiar. Tornou-se homem sem casa,e, para evitar a sensação de desabrigo, continua sua busca por novas terras (até mesmo em outros planetas).

\section{Guerra ou Paz? Freud e Merleau- Ponty Analisam a Ética dos Novos Conflitos}

O privilégio do mercantilismo faz com que as ajudas econômicas (realizadas pelos países do primeiro mundo aos países pobres) ocultem novos imperialismos. Como observa Merleau-Ponty (1960 / 1991), ao converter as ajudas econômicas em ajudas militares, os governos escondem a violência sob declarações de paz. Os países que recusam esse tipo de ajuda são acusados de privarem suas populações dos benefícios propostos. Trata-se de um tipo de ofensiva que deixa o inimigo em uma posição culposa.

"Daí a estranha noção de ofensiva de paz: propor a paz é desarmar o adversário, é conseguir a adesão da opinião pública; logo, é quase ganhar a guerra. Mas, ao mesmo tempo, sente-se bem que não se deve ficar desmoralizado, que de tanto falar de paz encorajar-se-ia o adversário" (Merleau-Ponty, 1960/ 1991, p.268, gr. do autor).

Essas afirmações remetem à recente declaração de guerra feita pelos Estados Unidos da América e Grã-Bretanha ao Iraque. Nesse caso, os que querem a guerra tentam justificar a ameaça com a intenção de paz no Oriente Médio. Fazem a apologia da destruição de armas através das armas. Por meio de uma falsa democracia, pregam o fim das ditaduras. Fingem não ser absurda a espera de que a população do país atacado suporte a perda de seus entes e a destruição de suas casas em troca de comida e medicamentos. Os mesmos aviões que jogam bombas, jogam mantimentos.

Nos tempos atuais, os motivos das guerras não são claros, embora elas aconteçam. Talvez uma razão eficiente para a guerra citada seja encontrada na afirmação de Merleau-Ponty (1960/1991) que as doutrinas ocidentais são limitadas para aceitar o crescimento econômico da Ásia.

Sob a falsa reivindicação de igualdade de direitos, as grandes potências ocidentais demonstram a intolerância para com as diferenças e tentam colocar a opinião pública a favor do uso da força. Para tanto, utilizam-se de quaisquer discursos humanitários (não esqueçamos que Hitler considerava humanitário seu delírio de aperfeiçoar a raça humana). Toda forma de questionamento dessas ações agressivas é inviável, porquanto tais 
governos buscam acreditar em seus próprios argumentos para não terem abaladas suas bases políticas.

A perversidade de tais argumentos reflete-se na forma como esses governos estabelecem e desautorizam medidas políticas, sem, todavia, reconhecerem suas incongruências. Aliados tornam-se adversários e vice-versa. Os acordos estabelecidos para a manutenção da paz e dos recursos naturais, para a organização das produções e do comércio, são facilmente infringidos pelos próprios assinantes. Recentemente, tal fato é demonstrado pela decisão americana e inglesa de atacar o Iraque, apesar das resoluções da Organização das Nações Unidas serem contra essa iniciativa.

Em Reflexões Para os Tempos de Guerra e Morte (Freud, 1915 / 1980), artigo que comenta as características e efeitos da Primeira Guerra Mundial, Freud fica perplexo com a desobediência das nações civilizadas aos acordos estabelecidos. $\mathrm{O}$ autor entende que as guerras são necessárias para a acomodação das civilizações e em virtude da agressividade humana, mas deveriam ser feitas mediante o respeito a ordens éticas. "Haveria, naturalmente, o máximo de consideração pelas camadas não-combatentes da população _ pelas mulheres que não tomam parte nas atividades guerreiras e pelas crianças de ambas as facções que, quando crescerem, devem tornar-se amigos e auxiliares mútuos (...). Mesmo uma guerra como essa teria produzido bastante terror e sofrimentos, mas não interrompido o desenvolvimento das relações éticas entre os componentes coletivos da humanidade os povos e os Estados" (Freud, 1915/ 1980, pp. 314-315).

Verificamos que os efeitos das duas primeiras grandes guerras mundiais (países arruinados, populações dizimadas) não foram suficientes para determinar a ética nos novos conflitos. Ao lado dos discursos contra tais guerras, caminhava a construção de armas cada vez mais poderosas.

De acordo com o artigo citado, a Primeira Guerra produziu uma desilusão quanto ao futuro da humanidade ao desrespeitar as noções éticas. Esse desrespeito seria um dos resultados das mudanças nos modos como as civilizações atuais vivenciam suas culpas. Freud nota que, nos povos civilizados, quando os heróis voltam da guerra não são perturbados por pensamentos em relação aos inimigos que mataram. Isso, continua o autor, não é visto entre os selvagens. Estes, quando voltam da guerra, expiam suas culpas através de rituais antes de entrarem em suas aldeias e tocarem suas mulheres. Esse comportamento é devido à superstição relacionada aos espíritos vingativos dos mortos. A Psicanálise explica que tal superstição é, na verdade, um efeito do sentimento de culpa pelo homicídio: "..por trás dessa superstição, jaz oculta uma veia de sensibilidade ética que foi perdida por nós, homens civilizados" (Freud, 1915/1980, p. 334).

\section{A Atitude Frente à Morte na Atualidade}

Apoiados na análise freudiana da relação entre ética e sentimento de culpa pelo homicídio, pensamos na hipótese de que as mudanças no modo como a morte é atualmente pensada influenciam as formas e os graus de manifestações da violência.

Conforme Freud (1915/1980), o inconsciente é incapaz de considerar a própria morte. A morte só é experimentada mediante a perda dos entes queridos, e, para suportar o sofrimento causado por tal perda, o homem criou a idéia de que esses entes continuam a existir como espíritos. A criação de um mundo espiritual,no entanto, implica que os inimigos também continuem suas existências após a morte e possam, então, vingar seus assassinatos. O medo dessa vingança obriga os homens a matar somente com justificativas para o ato. Além disso, a Psicanálise compreende que mesmo as relações com as pessoas queridas são marcadas pela ambivalência afetiva. Assim, o ódio sentido pela pessoa amada produz a vontade inconsciente de sua morte e, se de fato essa morte vem a ocorrer (pelos mais variados motivos), o vivente tem razões para temer a retaliação do morto, além de experimentar um grande sentimento de culpa.

Podemos entender que o temor e o sentimento de culpa diante da morte dificultariam as conquistas buscadas pelas grandes civilizações. Para elas, é mais importante um homem que não teme e nem mesmo pensa na morte (tanto na própria como na dos outros). Dessa forma, supõe-se haver mais coragem para a guerra. Concluímos que os avanços científicos colaboram para esse afastamento em relação à morte, pois, ao transformar o homem em objeto, a ciência descaracteriza a morte, tornando-a científica ou estatística. Hoje, muitas vezes, ela é acompanhada à distância, através dos vidros dos hospitais ou pela televisão. Enfatizando o corpo enquanto objeto, o mundo científico torna as questões da alma piegas, ignorantes. Logo, não há mais motivos para se temer os mortos.

Freud não se refere à morte somente como fenômeno. Ela também é descrita como metapsicologia: Freud fala-nos em pulsão de morte. Neste trabalho, não temos o objetivo de esclarecer o conceito freudiano de pulsão e os avatares em torno da pulsão de morte. Apenas indicamos que, 
com esse conceito, o autor estabelece que a agressividade não surge como resultado de experiências de frustração, como reação à agressividade de outrem ou como mecanismo de defesa transformador da libido em ódio. A tese sobre a pulsão de morte diz que a agressividade está presente desde o início da vida humana: a princípio, como autodestruição (o que o autor denomina masoquismo original); depois, como agressão dirigida ao mundo externo (vale notar que uma dose de masoquismo permanece).

Para a teoria sobre a pulsão de morte, é fundamental a seguinte afirmação: "Se tomarmos como verdade que não conhece exceção o fato de tudo o que vive, morrer por razões internas, tornarse mais uma vez inorgânico, seremos então compelidos a dizer que o objetivo de toda vida é a morte, e, voltando o olhar para trás, que as coisas inanimadas existiram antes das vivas" (Freud, 1920 / 1980, p. 56, gr. do autor).

Enquanto os impulsos de morte buscam atingir o objetivo final da vida o mais rápido possível, a pulsão de vida interfere nesse processo a fim de prolongar seu caminho. O objetivo da vida é a morte. Trata-se, no entanto, da morte natural, garantida pelos instintos de autoconservação e de auto-afirmação. Assim, a direção da agressividade para o exterior é uma proteção para o organismo, pois se permanecesse somente interno, o impulso de morte destruiria o indivíduo.

O autor postula uma contradição irreconciliável entre as pulsões de vida e de morte, podendo haver no indivíduo o privilégio de uma delas. Vale considerarmos que qualquer tipo de intervenção sobre a prevalência da pulsão de morte é, na melhor das hipóteses, muito difícil. Isso devido ao caráter irredutível e destruidor desse impulso, que leva Freud (1921 / 1980) a concluir que há uma presteza humana em odiar.

Essa condição psíquica determina o caráter das relações entre as pessoas. Em Psicologia de Grupo e Análise do Ego (1921 / 1980), para descrever as relações humanas, Freud recorda a metáfora schopenhaueriana dos porcos-espinhos que se congelam porque não podem se aproximar muito do próximo. E conclui: "A questão fatídica para a espécie humana parece-me ser saber se, e até que ponto, seu desenvolvimento cultural conseguirá dominar a perturbação de sua vida comunal causada pelo instinto humano de agressão e autodestruição"(Freud, 1929 / 1980, p. 170).

De nossa parte, inferimos que não há regras para nossa civilização sair desse estado de confusão. Admitir nossas perdas e a caduquice de nossos discursos tradicionais talvez seja o primeiro passo para a criação de novos valores capazes de orientar o curso de nossos afetos. Porventura, mesmo na ausência de um Outro Absoluto capaz de nos guiar, que possamos percorrer o caminho em busca do bem de cada um, mas um bem que não se restrinja a interesses utilitários.

\section{Considerações Finais}

As definições do homem e da verdade sofrem transformações no decorrer do tempo. Essas transformações coincidem com as mudanças sazonais e determinam as características das relações humanas. Tal afirmação não desconhece o fato de que o homem é, dialeticamente, responsável e influenciado pelas referidas definições.

A época contemporânea apresenta uma indecisão a respeito da essência do homem e da verdade que se reflete nos comportamentos humanos.

A Psicanálise parte dessa indecisão para decifrar na essência humana um conflito entre dois modos de funcionamento psíquico: o inconsciente e o consciente. Assim, essa teoria ratifica a decadência do privilégio da certeza absoluta no homem.

A Psicanálise verifica que a civilização só consegue a inibição da agressividade humana através de promessas de felicidade e proteção. Portanto, para analisarmos as formas atuais de manifestação da violência, entendemos ser necessária a investigação sobre quais são as promessas que nossa civilização oferece aos homens a fim de que eles renunciem a alguns de seus impulsos agressivos.

Partindo dessa indagação, imaginamos que hoje a lógica entre promessa e sacrifício se dá de forma perversa. Nossa hipótese é a de que os discursos parentais, estatais e religiosos não são mais capazes de prometer proteção e felicidade, por isso os limites da agressividade estão comprometidos.

Na época em que há privilégio dos interesses utilitários e necessidade de controle científico, o homem é tratado como objeto. Em suas relações com os outros, ele, ao mesmo tempo, usa e é usado. Dessa maneira, observamos em nossa civilização uma prerrogativa das mercadorias, o que determina situações cuja violência, muitas vezes, é banalizada. Nesse contexto, o homem está confuso quanto aos seus desejos e ao seu lugar no mundo. Supomos que nossas sociedades prometem, através das mercadorias, justamente o alívio da melancolia causada por esse estado de confusão. Segundo nossas hipóteses, hoje há uma negação da angústia e do sacrifício.

Porém, acreditamos que, somente vivenciando a angústia e os sentimentos de perda, o homem poderá eleger novos valores capazes de orientar seus desejos e ações. 
Lara Cristina d'Avila Lourenço Rua Campos Sales, 398, apto. 81, Centro, Ribeirão Preto SP; CEP: 14015110. E-mail: laracdl@hotmail.com

D'AVILA LOURENÇO, L. C. O Complexo de Édipo na Teoria de Jacques Lacan. Dissertação de Mestrado, Universidade Federal de São Carlos. São Carlos, 2000 .

FREUD, S. Reflexões Para os Tempos de Guerra e Morte. Edição Standard das Obras Psicológicas Completas de Sigmund Freud, volume XIV. Rio de Janeiro: Imago, 1980(1915).

Além do Princípio do Prazer. Edição Standard das Obras Psicológicas Completas de Sigmund Freud, volume XVIII. Rio de Janeiro: Imago, 1980(1920).

Psicologia de Grupo e Análise do Ego. Edição Standard Brasileira das Obras Psicológicas Completas de Sigmund Freud, volume XVIII. Rio de Janeiro: Imago, 1980(1921).

Algumas Conseqüências da Distinção Anatômica Entre os Sexos. Edição Standard Brasileira das Obras Psicológicas Completas de Sigmund Freud, vol. XIX. Rio de Janeiro: Imago, 1980(1925).

. Inibições, Sintomas e Ansiedade. Edição Standard Brasileira das Obras Psicológicas Completas de Sigmund Freud, vol. XX. Rio de Janeiro: Imago, 1980(1926).

O Mal-estar na Civilização. Edição Standard Brasileira das Obras Psicológicas Completas de Sigmund Freud, vol. XXI. Rio de Janeiro: Imago, 1980(1930[1929]).
Por que a Guerra? . Edição Standard Brasileira das Obras Psicológicas Completas de Sigmund Freud, vol. XXI. Rio de Janeiro: Imago, 1980(1933[1932].

HAAR, M. Heidegger e a Essência do Homem. Lisboa: Instituto Piaget, 1990.

HEIDEGGER, M. El Ser y el Tiempo. Madrid: Fondo de Cultura Econômica, 1984.

1969(1960) Sendas Perdidas. Buenos Aires: Editorial Losada,

JURANVILLE, A. Lacan e a Filosofia. Rio de Janeiro: Jorge Zahar Editor, 1987.

LACAN, J. A Ética da Psicanálise. O Seminário, livro 7. Rio de Janeiro: Jorge Zahar Editor, 1991(1960).

MERLEAU-PONTY, M. Signos. Martins Fontes: São Paulo, 1991(1960).

SINATRA, E. S. Ideales del Fin de Siglo. Revista del Instituto del Campo Freudiano-Pharmakon, 8, n. 8, 2000, pp. 12-17.

VIGANÒ, C. Toxicodependencia. Revista del Instituto del Campo Freudiano-Pharmakon, 9, n. 8, 2000,pp.18-27. 